\title{
Deed of Settlement as A Dispute Object based on HIR and Supreme Court Regulation No. 1/2016
}

\author{
Hazar Kusmayanti1 ${ }^{1}$ Lucky Dharmawan ${ }^{2}$ \\ ${ }^{1}$ Faculty of Law, Universitas Padjadjaran, Indonesia \\ hazar.kusmayanti@unpad.ac.id \\ 2 Faculty of Law, Universitas Padjadjaran, Indonesia \\ lucky.dharmawan@gmail.com
}

\begin{abstract}
Introduction to The Problem: It is uncommon for a case that has been decided by a judge and has the legal force to be retained and then brought back to Court by one party for a lawsuit. This kind of case contradicts the principles and applicable law, such as the case that the researcher found in Case No. 22/Pdt.G/2016/PN. Sal.

Purpose/Objective Study: This paper intends to discuss the legal problem of the resubmission of the deed of settlement as the object of a breach.

Design/Methodology/Approach: This research is doctrinal legal research. The data are secondary data which analyzed qualitatively. Following the approach method used, the study is conducted on norms and principles contained in secondary data, from the primary, secondary, and tertiary legal materials

Findings: The results of the study show that, first, deed of settlement cannot be an object of default because it has been inkracht. Secondly, Salatiga court judges did not consider the principle of ne bis in idem under Article 10 (1) The Judicial Power Act. The president of judges shall be able to carry out the role or power under Article 119 of the HIR, which is to provide advice to those who wish to file a lawsuit.
\end{abstract}

Paper Type: Research Article.

Keywords: ne bis in idem, deed of settlement, inkracht

\section{Introduction}

In practice, the agreement that has determined the rights and obligations of the creditor and debtor allows that the agreement cannot be carried out by the debtor as it should. This condition is then called default, which is a situation where the debtor does not fulfil what has been required (achievement) in the agreement, not because of a forced or overmacht condition. In connection with the preceding, if the debtor has defaulted, then the creditor will arise to claim compensation to the debtor. The compensation can be a substitute for the main achievement if the debtor does not fulfil his achievement at all or can also be an addition to the main achievement if the debtor is late in performing or performing poorly.

For compensation claims above, the creditor may file a lawsuit to the Court. The Court could be within the jurisdiction of legal domicile agreed by the parties in the agreement or the jurisdiction where the defendant lives or the principle of the actor 
sequitur forum rei, except if the defendant's residence is unknown, then the lawsuit shall be filed to the District Court within the plaintiff's residence (Mertokusomo, 2009).

Both disputing parties may determine the choice of law procedure, whether to solve the dispute through the Court or outside the Court. However, the best dispute resolution is by peace (Firmansyah, 2017). Peace was born from an agreement. Approval is an act wherein one person or more binding themselves towards one or more other people (Agung, 2016).

The role of judges in the effort to resolve civil cases peacefully is significant. Peace shows that the dispute has been resolved. The settlement is fast, and the costs are light. Mediation resolution, in its development, becomes part of the court settlement. After the party file and register the lawsuit, in the first trial, the judges will order both parties to carry out mediation and assign a mediator appointed by the parties. A mediator must be able to carry out its role so it can achieve the mediation goals (Mulyana, 2019).

Article 27 (1) Supreme Court Regulation No. 1 of 2016 (hereinafter as referred to as Perma No. 1/2016) determines that if the mediation process succeeds in reaching an agreement, the parties with the assistance of the mediator shall formulate a written agreement referred to as the peace agreement. The parties and the mediator must sign the agreement. Based on this Perma, the parties, through the mediator, can submit peace agreement to the judges to be strengthened in the form of a deed of settlement.

The Judge's decision will approach justice if taken through the process of interpretation of the law. A judge, for example, at each a reading that sets something approaching justice when maintaining the law while destroying or removing statute; therefore, every moment on its essence is unique. The judges shall continuously conduct legal interpretation (always new); thus, a decision may result in approaching justice. Without that, a decision cannot be considered fair; despite the decision, this is valid. Moment of decision making is a continuum where people maintain time series, but a decision that fair must tear time and defy against various dialectics (Melani, 2014).

Peace in civil procedural law, known as "dading," is an agreement of the disputing parties to end the dispute over a moderate matter settled by the Court (Khaira, 2018). This peace effort is necessary and must be included in the official report (processverbaal). If the Judge fails to reconcile, the failure must also be manifested in the minutes of the hearing. Failure to mention this in the official report results in the examination of the case containing a formal defect and resulting in a null and void examination. A judge who ignores the reconciliation stage and enters the questionand-answer examination stage is deemed to have violated the procedural code of conduct (Harahap, 2017). 
Dispute resolution can be settled in court or outside the court. Non-litigation settlement begins with the dissatisfaction of the process of dispute resolution through the court, which takes a relatively long time and requires no small cost. Other than that, decisions made by the Court often cause dissatisfaction between the parties, or some feel that they are the "losers." (Sri Mamudji, 2004). Dewi Rezki Sri Astarini, in her book entitled "Mediation of the Courts One Form of Dispute Resolution Based on the Principles of Quick Judgment, Simple Low Cost," mentions that the mediation process may result in 2 (two) possibilities: the success and the failure to reach an agreement, which can be strengthened in the form of a deed of settlement (Noor et al., 2019). If a peace agreement is reached, based on the Supreme Court Regulations mediation in article 17 states if peace is successfully carried out at the mediation stage in Court will be set forth in a deed and has an executorial power, if one party defaults or does not carry out its agreement which is written in the deed of settlement, the opposing party can immediately make an application for execution.

In practice, sometimes, a deed of settlement may not be carried out by either party or even by both parties. This condition might occur due to dissatisfaction with the deed of settlement. Therefore, the injured party will probably continue striving for their rights through certain mechanisms, even though this is contrary to the provisions of the applicable law. A judge in examining and handling a case in Court is required to be careful in carrying out his duties. In practice, it is not uncommon for a case that has been decided by a judge and has a legal force to be resumed and then brought back to the Court by a party for a lawsuit, which contradicts the principles and applicable law.

Ne Bis In Idem, or what in Dutch called exceptie van gewijsde zaak, means that the same case cannot be prosecuted twice. When a case has been submitted to a court and decided by the judges, and the decision has obtained permanent legal force, then the case may not be filed for a new lawsuit. This concept relates to court decisions that have obtained legal force that must never be changed or contested. Positive law in Indonesia itself is familiar with what is referred to as the ne bis in idem principle that determines that the same case cannot be tried a second time. Regulations regarding the principle of ne bis in idem itself are contained in Article 1917 of the Indonesian Criminal Code. When ne bis in idem principle are applied in the Court, it will be related to competition between which Court has the authority and is not authorized in handling cases, mainly to provide legal protection for the accused (Bernard, 2011).

Based on the explanation above, the authors found a civil case concerning the default on the Deed of Settlement No. 35/Pdt.G/2007/PN.Sal. This case was registered in the Salatiga District Court, with case register number 35/Pdt.G/2007/PN.Sal. This case is a civil case regarding a breach of contract. The beginning of this case occurred, in 1965, the Salatiga City Government borrowed land owned by Agus Sujarwo's parents, the late Atmodihardjo. In that year, the land originally owned by Agus Sujarwo's parents was used as market land. Over time, the land's function was altered to school land in 1974. This paper analyzes: 1) How is the position of Deed of Settlement 
No.35/Pdt.G/2007/PN.Sal as an object breach lawsuit based on HIR and Perma No. $1 / 2016$ ? And 2) How is the Indonesian legal arrangement regarding the actions of the judges in Salatiga District Courts who examine the case No. 35/Perdata.Gugatan/ 2016/PN.Slt and how is the Judge's consideration in deciding the case as inadmissible?

\section{Methodology}

This research uses a normative juridical approach through the principles of law and legal systematics (Soemitro, 1980). In accordance with the approach method, the study is conducted on norms and principles contained in secondary data, which are spread in primary, secondary, and tertiary legal materials, including a study of laws on civil proceedings, event books civil and judicial decisions, articles in journals related to the object of research.

\section{Results and Discussion}

Position of Deed of Settlement Number 35/Pdt.G/2007/PN.Sal as an object of Lawsuit on the Ground of Breach based on HIR and Perma Number 1 of 2016.

Disputes between the parties are generally social disputes. This social dispute can occur if the wishes of one party clash with the wishes of the other party. If the problem or social dispute is a difference in the scope of the legal order, then it will become a problem/legal dispute (Paputungan, 2017). An agreement of peace will be made if the parties reach a meeting point in the mediation. To make it has legal force, the parties can ask the panel of judges to strengthen it in a deed. A deed in question is commonly known as a deed of settlement. The deed of settlement has the same position as the ordinary Judge's decision, which has permanent legal force. Once the parties request to formalize their peace agreement in the form of a deed of settlement, then they are bound by the legal consequences which are not permitted to file an appeal. The rule is confirmed in Article 130 (3) HIR, "party shall not be permitted to appeal against such a decision."

In the deed of settlement, judges determine to punish both parties to obey the deed as an agreement in the mediation process. The judges' decision shall be included in the types of condemnatory decisions. In connection with Agus Sujarwo's actions in resubmitting a breach lawsuit over the non-implementation of the Deed of Settlement to Salatiga District Court, the verdict that should have been handed down The Salatiga District Court Judge in case number 22/Pdt.G/2016/PN/Sal is stating that the lawsuit is inadmissible or NO (niet ontvankelijke verklaard) with legal considerations that the lawsuit has been settled and decided before (ne bis in idem) and has inkracht gewjisde.

The Deed of Settlement No. 35/Perdata.Gugatan/2016/PN.Slt in a quo case is included in the deed, which is known in law as acta van vergelijke, is the meaning of the deed meant in Article 130 HIR. Acta van vergelijke referred to in Article 130 HIR is a deed made with the knowledge of the Judge in a case that has succeeded in peace 
in the Court. Thus, it is equated with the decision of a judge who has inkracht, so it cannot be appealed, because that is the power of execution (Damis, 2018).

Ne bis in idem is a principle of law that generally applies, both in the field of civil and criminal law. In civil law, this principle means cases with the same object, the same subject (party), and the same subject matter of dispute, which have been decided by a court of law and have permanent legal force with a positive decision (grant or reject), may not be re-examined for the second time (Butarbutar, 2018).

In the research, it was found that there was a discrepancy between the positive legal arrangements in force and the practices that occurred in the Salatiga City District Court which re-handled a case that had been decided through a deed that had obtained permanent legal force, in which Panel of Judges who handled the case in its decision handed down a decision where the contents state that a lawsuit filed by the plaintiff cannot be accepted not a lawsuit denied. A lawsuit declared as inadmissible or NO (niet ontvankelijke verklaard) by the Panel of Judges means that the claim has a formal disability, the claim is still premature.

Based on the facts that occurred in the trial, the parties involved in the dispute with case register number 22/Pdt.G/2016/PN.Sal is the same parties in cases that have been resolved before through mediation, which then results in a peace agreement being strengthened in the deed of settlement. In this case, the parties are Agus Sujarwo, and Deny Setya Wibowo. The object is the same object in the case that has been resolved through mediation, which then results in a peace agreement that is strengthened in the deed of settlement. The object of dispute in the two cases is a plot of land of around $1300 \mathrm{~m} 2$ in the name of Admodihardjo, located in Kutowinangun Village.

Agus Sujarwo should not need to re-submit a lawsuit over the non-implementation of the deed of settlement by the Salatiga Municipal Government and the Salatiga City Education and Culture Office. Why is that, because in Article 130 paragraph (2) HIR itself is said that the deed of settlement has the same legal force as the ordinary Judge's decision that has permanent legal force. Efforts that can be taken by Agus Sujarwo, who, in this case, is the aggrieved party due to the non-implementation of the Deed of Settlement, should be enough to request implementation decision or execution to the Head of the Salatiga District Court.

In this regard, not all judges' decisions can be carried out in the true sense of the word by force by the Court (Mertokusomo, 2009). Only condemnatory decisions can be implemented. If related to the case being discussed at the moment, the deed of settlement No. 35/Perdata.Gugatan/2016/PN.Slt there in the ruling contains a condemnatory decision marked by the sentence "Punishing the parties in this case to obey the provisions in the deed of settlement dated December 7th, 2007 ". So, in this case, it can be carried out voluntarily or by force. The deed of settlement is the same as the Judge's decision (in kracht van gewijsde), it has executive power. Thus, it must 
be carried out by the parties, filing a lawsuit and the case that has been decided together with the deed of settlement removes the power from making a deed of settlement stated in Article 130 of the HIR along with the Perma No. 1 of 2008. A deed of settlement must be made in writing and signed because it is a compulsory obligation in which the provisions concerning it are contained in Article 27 (1) of Perma No. $1 / 2016$.

Peace is not a decision determined by the Court's responsibility, but rather as an agreement between the two parties for their responsibility. Because peace took place before a court hearing (Murniati, 2016), the panel of judges make of deed of settlement according to the wishes of the parties to the case. A written deed of settlement is as evidence submittable to the Court if something happens outside agreed matters in the future. The deed a quo has fulfilled the requirements, such as be in written and signed by the parties. In this case, the peace agreement was made in writing and had been corroborated by the decision of the deed of settlement from the Judge of the Salatiga District Court number 35/dt.G/2007/PN.Sal.

The deed of settlement in a quo case is made by parties which in this case have met the qualifications as people who have the power to make a deed of settlement. Arrangements regarding a person's ability to make a deed of the settlement are regulated in Article 1330 jo. Article 330 Criminal Code. Referring to that article, if interpreted in a contrario manner, people who are considered mature and capable of doing according to the law are adults who are 21 years of age or older.

In this case, the deed of settlement Salatiga Court was made by Agus Sujarwo, and Deny Setya Wibowo. At the trial, the parties already have the authority and capacity as a stand in judicio person so that when referring to the provisions in the civil law regarding the ability to make an agreement, which in this case is a deed of settlement, then they have fulfilled the qualifications.

Based on the author's analysis, the actions taken by Agus Sujarwo who have again sued the Salatiga City Government and the Salatiga City Education and Culture Office can be possible due to ignorance on Agus Sujarwo's own side of the existence of a law governing the implementation of a decision on the non-implementation of a deed of settlement that has been carried out legally binding so that he eventually filed a lawsuit again at the Salatiga District Court.

Indonesian Positive Legal Arrangements Regarding the Actions of Salatiga District Court Judges Who Examine the Lawsuit on the ground of the NonPerforming of Deed of Settlement Number 35 / Pdt.G / 2007 / PN.

Civil procedural law in court proceedings plays a significant role, especially in regulating disputes between individuals (Jacob, 2010). Therefore, talking about civil procedural law will not be separated from the justice system in Indonesia. Based on the Constitution, the judiciary power is exercised by the Supreme Court along with the judicial body under it and a Constitutional Court. The judicial body under the 
Supreme Court covers the judiciary in the environment: 1 . General Court; 2. Religious Courts; 3. State Administrative Courts, and 4. Military Courts. Case hearings in all judicial bodies take place in two levels, namely the first level and the appeal level. These courts are authorized to examine the facts (judex facti). The Supreme Court is not a third-level court, because it no longer checks the facts but checks the application of the law carried out by judex facti as the Court underneath, for that the Supreme Court is also referred to as judex juris (Ivan, 2016).

Based on the regulation in Article 25 of Law No. 48/2009, the party who has the authority to examine, hear, and decide on case No. 22/Pdt.G/2016/PN.Slt, namely regarding the dispute of breach of a lawsuit filed by Agus Sujarwo on nonimplementation of the deed of settlement by the Salatiga Municipal Government and the Salatiga City Education and Culture Office is the Salatiga District Court.

A principle bounds the Judge in examining and deciding cases in a court in Court, namely the principle of ius curia novit. The principle states that the rights, the judges are considered to know the law. The principle of ius curia novit in Indonesia derives from Article 5 (1) of Law No. 48/ 2009 concerning Judicial Power. Article 5 paragraph (1) states, "Judges and constitutional justices are obliged to explore, follow, and understand the legal values and sense of justice that lives in society" (Wicaksana, 2018). It goes in line with Article 10 (1) of Law No. 48/2009 concerning Judicial Power. The article essentially states that judges are prohibited from refusing, adjudicating, and adjudicating a case brought to him on the grounds he does not know the law or his law does not exist. In the case which the law has not been found or the regulation is not found in a particular statutory regulation, the Judge is obliged to make a legal finding here so that the verdict handed down gives benefits and creates a sense of justice for the community.

In the civil procedural law, there is also a principle of the Judge shall be waiting. This principle states that in the implementation of a civil case settlement in Court, the initiative to submit claims for rights is left to the interested parties. So, whether a case will be processed or not, whether a case or claim of rights will be submitted or not, fully submitted to the parties concerned. If there is no claim of rights or prosecution, there is no judge (Wo kein Klager ist, ist kein Richter, nemo judex sine actore) (Sutantio \& Oeripkartawinata, 2009). Referring to the principle, if there is a claim or claim of rights submitted to the Court, the Judge is forbidden to refuse, examine, and decide on the case submitted.

Based on the analysis of the author, the Salatiga District Court Judge Panel in the case verdict No. 35/Perdata.Gugatan/PN.Salatiga indeed has the power to accept, examine, and decide on the case submitted by Agus Sujarwo as the plaintiff. This is done to carry out what has been mandated by Article 10 section (1) of Law No. 48/2009 and to carry out the principle of civil procedural law, namely the principle of ius curia novit, that the Judge is considered to know the law. The Ius Curia Novit principle 
believes that every Judge knows the law, so he must try every case submitted to him. This principle was first discovered in the writings of medieval jurists (glossators) about ancient Roman law. Ius Curia Novit is a principle that views that "the judge knows the law" (the Court knows the law). Therefore, a judge has to determine what law must be applied to a particular case and how it is applied. This principle has long been known in the Civil Law system so that the parties to the dispute need not postulate or prove the law that applies to their case because the Judge is seen to know the law (Wicaksana, 2018).

Even though the Panel of Judges of the Salatiga District Court in the verdict in case No. 35/Perdata.Gugatan/PN.Salatiga has passed a decision stating that the lawsuit cannot be accepted, but, in its legal considerations, the Panel of Judges of the Salatiga District Court ignored the legal force of deed of settlement number 35/Pdt.G/PN.Sal, which was made the object of the default dispute.

In examining case judgment, the Panel of Judges of the Salatiga District Court has also carried out the principle of an active judge that is actively presiding over hearings and has given an opportunity to Agus Sujarwo as the plaintiff to submit a claim and answer to the defendant's exception. And to the Salatiga City Government and the Salatiga City Education and Culture Office as Defendants I and Defendant II to refute the plaintiff's claim through his exception. In every civil case, in this case, the lawsuit filed with the Court, the Chief Justice has the power to give advice or help to someone who filed the claim or to his attorney. Regarding the power of the head of the Court to give advice to someone who wants to file a lawsuit is regulated in Article 119 of the HIR.

Referring to the regulation, the Salatiga District Court, through its Chief Justice, should only provide help or advice to Agus Sujarwo as the plaintiff in case No. 35/Perdata.Gugatan/PN. Salatiga. In this case, the Chairperson of the Court was sufficient to notify Agus Sujarwo that his claim for breach of contract did not need to be re-submitted to the deed of settlement because in the provisions of Article 130 (2) HIR jo Perma Number 1 of 2016, it has been determined that the deed of settlement made in Court by the parties and assisted by a certified mediator, with the knowledge of the Judge (acta van vergelijke), has the same position like an ordinary judge's ruling. Although the Panel of Judges of the Salatiga District Court in the verdict in case No. 35/Pdt.G/PN.Salatiga has passed a decision stating that the lawsuit cannot be accepted, but in its legal considerations, the Panel of Judges of the Salatiga District Court ignores the legal force of deed of settlement, which was made the object of the default dispute.

The judges in their legal considerations stated that the lawsuit filed by Agus Sujarwo could not be accepted not because the lawsuit had been resolved beforehand (ne bis in idem) through the deed of the settlement but Agus Sujarwo's lawsuit in Case No.22/Civil. Lawsuit/2016/PN.Slt was declared unacceptable because Agus Sujarwo himself had not carried out his obligations contained in Article 5 of the deed of 
settlement dated December 7th 2007, namely submitting proof of land ownership to the Registrar of the Salatiga District Court. This occurrence indicates that Agus Sujarwo has fulfilled his obligations in Article 5 of the deed of settlement, which to submit the land ownership documents to the Registrar of the Salatiga District Court. There is a possibility of the case regarding the lawsuit by Agus Sujarwo over the nonimplementation of the Deed of settlement No. 35/Perdata.Gugatan/2016/PN.Slt by the Salatiga Municipal Government and the Salatiga City Education and Culture Office could be granted even though the deed of settlement has been empowered the law is permanent and has the same position as an ordinary judge's decision.

Based on the explanation, it is true that the Salatiga District Court Judge has the authority to examine and judge the case a quo. Then the verdict of the Salatiga District Court Judge in case Case No. 22/Civil.Lawsuit/2016/PN.Slt was correct, namely stating the lawsuit could not be accepted. However, in its legal considerations, the panel of judges paid little attention to the provisions of Article 130 paragraph (2) of HIR and Perma Number 1 of 2016. It essentially states that the deed of settlement, made in Court with the Judge's knowledge and has been completed, has the same position as the ordinary Judge's decision legally binding.

The actions of the Salatiga District Court Judges, which is not in accordance with Article 130 (2) HIR and Perma No. 1 of 2016 in examining and adjudicating case No. 35/Perdata.Gugatan/PN. Salatiga will clearly cause legal uncertainty in the future in the practice of proceedings in Court, especially in civil justice. The role of law in development is to ensure that it happens in a way that is done, the law is resolved through the help of invitations and court decisions, or a combination of all (Latipulhayat, 2014). Therefore the law requires coercion for the structuring of its provisions, so the law requests permission for its enforcement. This is the reason Mochtar called being incompatible in society about the laws that exist in a society that is governed by and based on the law. However, determining itself must regulate the limits determined by law, both on the way and space or its implementation (Aulia, 2018). Based on that case, it is feared that in the future similar case will be repeated, namely the submission of a lawsuit over the non-implementation of a deed of settlement made in Court and has a permanent legal force which attempts it should be enough to submit a request for execution to the Head of District Court.

\section{Conclusion}

Deed of settlement No. 35/Pdt.G/2007/Pengadilan Negeri Salatiga based on the provisions of Article 130 (2) HIR and Article 1 Number 10 Perma No. 1/2016 cannot be the object of a lawsuit, because its position is the same as the inkracht decision. If it is submitted again to the court, the deed of the settlement will subject to (ne bis in idem). The Actions of the Salatiga City District Court Judges who receive, examine, and decide upon Case No.22/Civil.Lawsuit/2016/PN.Slt is indeed justified by Article 10 (1) of the Law on Judicial Power. However, this regulation does not necessarily free Salatiga District Court to accept any cases that come in, including cases that have been 
decided before (ne bis in dem). Salatiga District Court, through the mediation of its Chairman should be able to carry out the role or power contained in Article 119 of the HIR that is giving advice to parties who want to file a lawsuit.

\section{References}

Agung, A. A. I. (2016). Akta perdamaian notariil dalam pembuktian di pegadilan. Jurnal Notariil, 1(1), 51-68. https://doi.org/10.22225/jn.1.1.107.51-68

Aulia, M. Z. (2018). Hukum pembangunan dari mochtar kusumaatmadja: mengarahkan pembangunan atau mengabdi pada pembangunan? Undang: Jurnal Hukum, 1(2), 363-392. https://doi.org/10.22437/ujh.1.2.363-392

Bernard, D. (2011). Ne bis in idem protector of defendants' rights or jurisdictional pointsman? Journal of International Criminal Justice, 9. https://doi.org/doi:10.1093/jicj/mqr018

Butarbutar, E. N. (2018). Asas ne bis in idem dalam gugatan perbuatan melawan hukum: kajian putusan nomor 65/PDT.G/2013/PN-RAP. Jurnal Yudisial, 11(1), 23. https://doi.org/10.29123/jy.v11i1.167

Damis, H. (2018). Konflik kewenangan absolut pengadilan akibat penentuan pokok sengketa yang berbeda. Jurnal Yudisial, 11(1), 75-89. https://doi.org/http://dx.doi.org/10.29123/jy.v11i1.20

Firmansyah, Y. R. (2017). Kekuatan hukum akta perdamaian yang dibuat dihadapan notaris dan putusan akta perdamaian pengadilan. Jurnal Cakrawala Hukum, 8(2), 220-229. https://doi.org/10.26905/idjch.v8i2.2114

Harahap, M. Y. (2017). Hukum acara perdata. Sinar Grafika.

Ivan, R. S. (2016). Tinjauan yuridis tentang peranan identitas domisili dalam menentukan kompetensi relatif pengadilan. Lex Privatum, IV(1), 24-32. https://doi.org/10.1017/CB09781107415324.004

Jacob, J. (2010). The reform of civil procedural law. The Law Teacher Journal, 44. https://doi.org/http://dx.doi.org/10.1080/03069400.1980.9992524

Khaira, U. (2018). Pelaksanaan upaya perdamaian dalam perkara perceraian (suatu kajian terhadap putusan verstek pada Mahkamah Syar'iyah Bireuen). Jurnal Penelitian Hukum De Jure, 18(3), 319-334.

Latipulhayat, A. (2014). Khazanah Mochtar Kusumaatmadja. In Padjadjaran Jurnal Ilmu Hukum (Vol. 1, Issue 3, pp. 626-642).

Melani. (2014). Disparitas putusan terkait penafsiran pasal 2 dan 3 uu pemberantasan tindak pidana korupsi. Jurnal Yudisial, 7(2), 103-116.

Mertokusomo, S. (2009). Hukum acara perdata di Indonesia. Liberty.

Mulyana, D. (2019). Kekuatan hukum hasil mediasi di dalam pengadilan dan di luar pengadilan menurut hukum positif. Jurnal Wawasan Yuridika, 3(2), 177. https://doi.org/10.25072/jwy.v3i2.224

Murniati, R. (2016). Relevansi dan kekuatan hukum akta perdamaian dalam penyelesaian sengketa di bidang ekonomi. Fiat Justisia, 9(1), 89-102. https://doi.org/10.25041/fiatjustisia.v9no1.590

Noor, T., Gulo, M., \& Putri, M. I. (2019). Analisis Hukum terhadap penyelesaian 
sengketa hutang piutang melalui akta perdamaian (studi putusan nomor: 1/Pdt.G.S/2017/PN. Blg). Jurnal Hukum Kaidah: Media Komunikasi Dan Informasi Hukum Dan Masyarakat, 18(3).

Paputungan, R. P. (2017). Kedudukan hukum akta perdamaian yang ditetapkan oleh hakim menurut hukum acara perdata. Lex Crimen, VI(8), 1689-1699.

Soemitro, R. H. (1980). Metodologi penelitian hukum dan jurimetri. Ghalia Indonesia.

Sri Mamudji. (2004). Mediasi Sebagai alternatif penyelesaian sengketa di luar pengadilan. hukum dan pembangunan, 34(3), 194-209.

Sutantio, R. W., \& Oeripkartawinata, I. (2009). Hukum acara perdata dalam teori dan praktek. Mandar Maju.

Wicaksana, Y. P. (2018). Implementasi asas ius curia novit dalam penafsiran hukum putusan hakim tentang keabsahan penetapan tersangka. Jurnal Lex Renaissance, 3(1), 86-108. https://doi.org/10.20885/jlr.vol3.iss1.art3 